\title{
Screening Cellulose Activity of Yeast Isolated from Soil, Sediment and Water River from Taman Nasional Gunung Halimun, West Java, Indonesia
}

\author{
Wibowo Mangunwardoyo $^{1 *}$, Aprilismulan ${ }^{1}$, Ariyanti Oetari ${ }^{1}$ and Wellyzar Sjamsuridzal ${ }^{1}$ \\ ${ }^{1}$ Department of Biology, Faculty of Mathematic and Natural Sciences, University of Indonesia, Depok, Indonesia 16424. \\ E-mail:w_mangunwardoyo@yahoo.com; wibowo.mangun@ac.ui.id
}

Received 5 January 2011; received in revised form 17 August 2011; accepted 4 September 2011

\begin{abstract}
A total of 245 yeast isolates from Gunung Halimun National Park (GHNP) were screened for cellulolytic activity using $0.2 \%$ cellulose-azure. The results showed that 16 isolates have cellulolytic activity using cellulose-azure assay. These isolates were further screened for carboxymethyl cellulase (CMCase), avicelase and cellobiase using specific substrates (carboxymethyl cellulosa, avicel and cellobiose) with Teather and Wood method. The results showed that 7 isolates have CMCase; 6 isolates have cellobiase; 2 isolates have CMCase and cellobiase; and 1 isolate has CMCase and avicelase and cellobiase activities. Isolate $S 4121$ has the highest CMCase activity and identified as Trichosporon sporotrichoides (van Oorschot) van Oorschot and de Hoog UICC Y-286.
\end{abstract}

Keywords: Avicelase, cellobiase, cellulolytic activity, CMCase, yeast.

\section{INTRODUCTION}

Cellulose is a glucose polymer with $\beta-1,4$-glycosidic bond (Han et al., 1995; Murai et al., 1998). The hydrolysis of cellulose involves three components of enzymes, exoglucanase (1,4- $\beta$-D-glucan cellobiohydrolases) (EC 3.2.1.91), endoglucanase (endo-1,4- $\beta$-D-glucan-4 glucanohydrolases) (EC 3.2.1.4) and ( $\beta$-D-glucoside glucohydrolases or $\beta$-D-glucosidase) (EC 3.2.1.21) (Kim, 1995; Saha and Bothast, 1996; Ilmen et al., 1997).

The cellulase components of fungal and yeast have a different components. Aspergillus oryzae produce $\beta$ glucosidase and Trichoderma reesei excreted of three component of cellulase (Kubicek et al., 1993). Candida wickerhamii have intracellular, extracellular, and cellbound $\beta$-glucosidase, (Skory and Freer, 1995). Candida peltata, Debaryomyces, Kluyveromyces and Pichia produces extracellular $\beta$-glucosidase (Saha and Bothast, 1996).

Screening of fungal isolates capable of producing large amount of cellulolytic enzyme must be fast, simple, and effective. The cellulose azure method is one of the choices where cellulose was embedded with azure. The activity is indicated by the release of the azure dye from the bound cellulose and azure, the intensity of blue dye indicates the activity of cellulase (Smith, 1977). The three components of cellulase can only degrade the specific substrate. Endoglucanase activity can be detected using amorf carboxymethyl cellulose (CMC) (Coral et al., 2002). Assays of exoglucanase using microcrystalline cellulose (Avicel) as a substrate crystalline pure cellulose (Kim, 1995). Cellobiase can be detected using cellobiosa as a substrate (Skory and Freer, 1995).
The quantitative assay of the component cellulose was detected using the specific substrate. One of the methods was a clear zone around the colony using the Congo red stain (Teather and Wood, 1982). The stain of Congo red binds the $\beta-1,4$-glucoside polymer specifically. Degradation of the $\beta-1,4$ glucoside link, the enzyme activity that cause the Congo red will not able to bound with polymer, consequently, the hallo will appear on the medium (Yuan et al., 2001).

University of Indonesia Culture Collection (UICC) have collection of yeast isolated from soil, water river and sediment from Taman Nasional Gunung Halimun (TNGH), Jawa Barat, Indonesia. The isolate have not been examined for ability to produce cellulase.

The purpose of the research is to screen the yeast isolates for cellulase production from TNGH and to analyze the component of the enzyme on the specific substrate.

\section{MATERIALS AND METHODS}

\section{Isolates}

Amount of 245 isolates from the University of Indonesia Culture Collection (UICC) were isolated from soil, river water and sediment at TNGH. Positive control used was P 2112 and negative control was Saccharomyces cerevisiae var. ellipsoideus UICC Y-17.

\section{Media}

Yeast Malt Agar (YMA), Potato Dextrose Agar (PDA), agar medium $0,75 \%$ and Yeast Nitrogen Base Agar 
(YNBA) (Difco) was added celulose-azure 0,2\% (Sigma), and Yeast Nitrogen Base (YNB) (Difco) was added carboxymethyl cellulose (CMC), avicel, and cellobiose $0.1 \%(b / v)$

Screening medium cellulase activity with $0.2 \%$ according to Smith (1977) with some modification

The cellulose azure medium was divided in two parts. The first was a bottom mixture of $7.5 \mathrm{~g}$ agar/L. The mixture was heated and $7 \mathrm{~mL}$ of the agar used to fill the tube approximately $5 \mathrm{~cm}$ in high, sterillized and allowed to solidify in stand position. The upper part of medium consisted of cellulose-azure $0.2 \%$ with YNBA medium. YNBA medium was made according to Van der Walt and Yarrow (1984) with composition 26.05 g YNBA/600 mL aquadest. At the separate component $2 \mathrm{~g}$ celluloseazure $/ 400 \mathrm{~mL}$ aquadest. The two component were sterillized separately, further mixed and vortexed. A 0.5 $\mathrm{mL}$ mixture was added to the agar medium, the medium was allowed to solidify.

Screening medium on specific substrate (CMC, avicel and cellobiosa $0.1 \%(\mathrm{w} / \mathrm{v})$

The screening medium was prepared according to Teather and Wood (1982). The composition were $5 \mathrm{~g}$ $\left(\mathrm{NH}_{4}\right)_{2} \mathrm{SO}_{4}, 0,5 \mathrm{~g} \mathrm{MgSO}_{4} \cdot 7 \mathrm{H}_{2} \mathrm{O}, 1 \mathrm{~g} \mathrm{KH}_{2} \mathrm{PO}_{4}$ and $20 \mathrm{~g}$ agar in $1 \mathrm{~L}$ aquadest. The medium was prepared in four Erlenmeyer flask, three of the them were added $0.25 \mathrm{~g}$ CMC, Avicel, and cellobiose $0.1 \%(w / v)$, the sterillized medium was pour in the Petri dish, after solidify the agar punched with cork borer diameter $0.75 \mathrm{~cm}$.

\section{Screening cellulolytic on medium cellulose-azure $0.2 \%$}

Amount $100 \mu \mathrm{L} \quad\left(0.30-3.00 \times 10^{8} \mathrm{cell} / \mathrm{mL}\right)$ yeast suspension were inoculated on the top of cellulose azure medium and incubated for 30 days in room temperature. The cellulolytic activity was observed of the intensity of azure diffuse in the agar.

\section{Screening using substrate CMC, avicel and cellobiose $0.1 \%(w / v)$}

The selected potential yeast were further assay using this method base on the cellulose azure method, $30 \mu \mathrm{L}(0.30$ $3.00 \times 10^{8} \mathrm{cell} / \mathrm{mL}$ ) cell suspension were inoculated in the hole of YNBA with $0,1 \%$ specific substrate. The Petri dish with four punched hole with YNBA medium and specific substrate consist of the first hole inoculated with cell suspension, second hole for control positive ( $P$ 2112); third hole for negative control (Saccharomyces cerevisiae var. ellipsoideus UICC Y-17); and the fourth hole as a medium control, was incubated for 6 days in room temperature. The experiments were done in triplicate. After incubation the solution of Congo red $0.2 \%$ was dropped in the surface of covered the medium remaining Congo red was taken with the pipette, the medium assay was incubated for $24 \mathrm{~h}$. The hallo diameter indicated the cellulose activity of the yeast.

Indexes cellulase activity (ICA) according to Kader and Omar (1998):

$\mathrm{ICA}=\frac{\text { Diameter clear zone }- \text { Diameter yeast colony }}{\text { Diameter yeast colony }}$

\section{DNA preparation}

The yeast culture was cultivated in YM broth (containing 3 $\mathrm{g}$ of yeasts extract, $3 \mathrm{~g}$ of malt extract, $5 \mathrm{~g}$ of polypeptone and $10 \mathrm{~g}$ of glucose per $1 \mathrm{~L}$ of aquadest), and the cells were harvested during the logarithmic phase of growth and collected by centrifugation. The DNA was extracted and purified by using the method of Sjamsuridzal and Oetari (2003).

\section{Amplification of D1/D2 of LSU rDNA}

The D1/D2 region of nuclear large subunit ribosomal DNA was amplified and sequenced using the primer sets, NL1 (GCATATCAATAAGCGGAGGAAAAG) and NL4 (GGTCCGTGTTCAAGACGG) as described by White et al. (1990). D1/D2 region is located between nucleotide positions of 40 to 654 of 26S rRNA gene of Saccharomyces cerevisiae (Gutell and Fox, 1988). PCR was carried out in $25 \mu \mathrm{L}$ reaction volumes with a PerkinElmer GeneAmp PCR System 9700 (Perkin Elmer, Foster City, CA, USA) as follows: 4 min of denaturation at $95^{\circ} \mathrm{C}$, followed by 35 cycles each with $1 \mathrm{~min}$ of denaturation at $94^{\circ} \mathrm{C}, 45 \mathrm{sec}$ of annealing at $53^{\circ} \mathrm{C}$, and $1 \mathrm{~min} 15 \mathrm{sec}$ of extension at $72^{\circ} \mathrm{C}$; with a final 8 min extension step at 72 ${ }^{\circ} \mathrm{C}$ after cycling was completed.

\section{Sequencing of D1/D2 of LSU rDNA}

The nucleotide sequences were determined with Big Dye Terminator v3.1 Cycle Sequencing Ready Reaction Kit (Applied Biosystems) following the manufacturer's instructions. The gel electrophoresis and data collection were performed on ABI Prism Genetic Analyzer (Applied Biosystems). The sequencing results were compared with DNA sequences from GenBank database at National Center of Biotechnology Information (NCBI) using the Basic Local Alignment Search Tool (BLAST) program for screening sequence similarity (Altschul et al., 1997).

\section{RESULTS AND DISCUSSION}

\section{Screening cellulase activity using cellulose azure $0.2 \%(w / v)$}

A total 245 of yeast collection of UICC isolated from NTGH were screened using cellulose-azure $0.2 \%(\mathrm{w} / \mathrm{v})$. The results showed 16 isolates released the dye colour of azure diffuse in the basal of agar. Two isolates changed 
the azure become whitish and eight isolates turn to white bluish and two isolated changed azure to blue whitish (Table 1 and Figure 1). The isolates yeast from TNGH was able to released the dye indicate that azure become white, whitish blue and blue indicated potential on cellulase producer, however, the azure still blue did not release in the agar no cellulose activity for those fungus (Smith, 1977).

Table 1: Results of the assays cellulolytic activity using cellulose-azure method yeast isolated from TNGH

\begin{tabular}{|c|c|c|c|}
\hline Origin & Isolates code & Positive cellulolytic activity & Notes \\
\hline \multirow{9}{*}{ Soil } & $\begin{array}{l}\text { S } 4111-\text { S } 41115 \\
\text { except S } 41112\end{array}$ & negative & \\
\hline & $\begin{array}{l}\text { S } 4121-\text { S } 4124 \\
\text { except S } 4123\end{array}$ & S $4121(++)$ & filamentous \\
\hline & $\begin{array}{l}\text { S } 4131-\text { S } 4134 \\
\text { except S } 4133\end{array}$ & $\begin{array}{l}\text { S } 4132(++) \\
\text { S } 4134(++)\end{array}$ & $\begin{array}{l}\text { filamentous } \\
\text { filamentous }\end{array}$ \\
\hline & - S $4212-\mathrm{S} 42112$ & S $4215(+)$ & filamentous \\
\hline & - S $4221-$ S 4223 & negative & \\
\hline & $\begin{array}{l}\text { - S } 4231-\text { S } 42321 \\
\text { except S } 42320\end{array}$ & $\begin{array}{l}\text { S } 42315(++) \\
\text { S } 42318(++)\end{array}$ & $\begin{array}{l}\text { filamentous } \\
\text { filamentous }\end{array}$ \\
\hline & - S 4311 & negative & \\
\hline & - S $4321-$ S 4325 & S $4321(+)$ & filamentous \\
\hline & - $\quad S 4331-S 4337$ & negative & \\
\hline \multirow{6}{*}{ Sediment } & $\begin{array}{l}\text { SD } 4111-\text { SD } 41126 \\
\text { except SD } 41120\end{array}$ & SD $41124(++)$ & filamentous \\
\hline & $\begin{array}{l}\circ \text { SD } 4121-\text { SD } 41223 \\
\text { except SD } 41211\end{array}$ & $\begin{array}{l}\text { SD } 4124(+) \\
\text { SD } 41219(++)\end{array}$ & $\begin{array}{l}\text { filamentous } \\
\text { filamentous }\end{array}$ \\
\hline & $\begin{array}{l}\text { SD } 4134-\text { SD } 41313 \\
\text { except SD } 4135, \text { SD } 4137, \\
\text { SD } 4138\end{array}$ & negative & \\
\hline & $\begin{array}{l}\circ \text { SD } 4211-\text { SD } 4215 \\
\text { except SD } 4214\end{array}$ & negative & \\
\hline & $\circ \quad$ SD $4221-$ SD 42210 & SD $4223(+)$ & filamentous \\
\hline & $\begin{array}{l}\text { SD } 4232-\text { SD } 4238 \\
\text { except SD } 4237\end{array}$ & negative & \\
\hline \multirow{6}{*}{ Water river } & $\begin{array}{l}\text { W } 4111-\text { W } 41119 \\
\text { except W } 4116\end{array}$ & negative & \\
\hline & $>\quad W 4121-W 41223$ & W $41210(+)$ & no filamentous \\
\hline & $\begin{array}{l}>\quad W 4131-\text { W } 41323 \\
\text { except W } 4133, \text { W } 41313\end{array}$ & W $41320(+)$ & filamentous \\
\hline & $\begin{array}{l}\text { W } 4211-\text { W } 42117 \\
\text { except W 4213, W 4218, } \\
\text { W 42111, W 42115 }\end{array}$ & negative & \\
\hline & $\begin{array}{l}\text { W } 4222-\text { W } 42221 \\
\text { except W 4223, W 4224, } \\
\text { W 4229, W 42210, } \\
\text { W 42213, W 42214, } \\
\text { W 42216, W 42220 }\end{array}$ & negative & \\
\hline & $\begin{array}{l}\text { W } 4233-\text { W } 42321 \\
\text { except W } 4239, \text { W } 42314, \\
\text { W } 42315, \text { W 42319, } \\
\text { W } 42320\end{array}$ & $\begin{array}{l}\text { W } 4233(+++) \\
\text { W } 4234(++) \\
\text { W } 42317(+++)\end{array}$ & $\begin{array}{l}\text { filamentous } \\
\text { no filamentous } \\
\text { no filamentous }\end{array}$ \\
\hline
\end{tabular}

Notes : (+) blue whitish; (++) white bluish, (+++) whitish 


\section{Screening using specific substrate}

Screening using specific substrate for sixteen isolate showed seven isolate produce CMCase, six isolate secreted cellobiase, two isolates produced CMCase and cellobiase, only one isolate produced three component of cellulase (CMCase, avicelase, and cellobiase) (Table 2). Screening using cellulose azure 0,2 \% (w/v) (Smith method) a total 245 yeast isolate from UICC, only 16 have ability to release the azure from the cellulose-azure bound.

Smith (1977) reported 283 of fungal isolated using cellulose azure methods. The cellulose will degrade bound of azure and cellulose, the blue dye diffusion to the agar, the high intensity of colour indicate the potential degradation of cellulose. Sudiana and Rahmansyah (2002) reported yeast was a one of the organism as a cellulose producer. The genus Candida, Debaryomyces hansenii, Pichia membranifaciens, Rhodotorula minuta as yeast produce the cellulose isolated from TNGH.

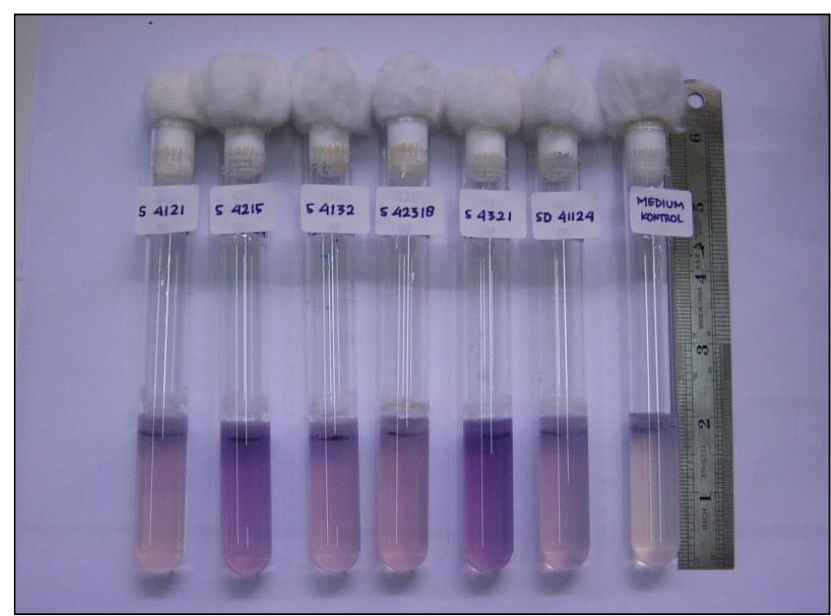

Figure 1: Changes of colour cellulose-azure assays using Smith (1977) method.

The experiment for cellulose azure method was conducted for 30 days, the period of time will allow the fungus to degrade link of azure and cellulose. Fadel (2000) reported that each microorganism have the different incubation time to do the enzymatic reaction to the substrate. Smith (1977) screened the cellulolytic activity was incubated for 10 days at $25^{\circ} \mathrm{C}$ for mesophyllic Aspergillus niger, Myrothecium verrucaris and Trichoderma viride; incubation period 5 days at $45^{\circ} \mathrm{C}$ for the thermophilic mold Sporotrichum thermophile. Lim et al. (1985) used cellulose-azure for screened cellulase activity 11 molds Aspergillus niger with 10 days incubations, then out of them have a positive results and one negative. Prasertsan et al. (1992) using degradation of filter paper to examine the FPase activity. The fungus Trichoderma reesei TISTR 3080, T. reesei QM9414, T. viride TISTR $3167, \quad T$. reesei TISTR 3230 and Sporotrichum pulverulentum TISTR 3226 indicated FPase activity after eight days incubation, moreover Myrothecium verrucaria TISTR 3225 needed longer period for 11 and 14 days.

Screening cellulolytic activity using the basal medium of YNB and substrate cellulose-azure 0,2\% (w/v). Van der Walt and Yarrow (1984) reported that medium of Yeast Nitrogen Base Agar (YNBA) was able to use as medium basal on cellulose activity as an nitrogen sources and its did not contains of carbon sources. Coral et al. (2002) cellulose-azure as a cellulosic substrate and as a carbon sources for cellulolytic assays, cellulose-azure is a natural $\alpha$-cellulose. Raimbault (1998) and Ojumu et al. (2003) mentioned that natural cellulose have a crystalline structure and lignin, its difficult to degrade for cellulolytic microorganism or any agent hydrolytic sources.

Coral et al. (2002) and Murai et al. (1998) reported that cellulosic materials only degrade by one component cellulase. CMC is one of cellulosic substrate degrade by endoglucanase or CMCase. Kim (1995) mentioned microcrystalline cellulose (avicel) as a cellulolytic substrate degrade by exoglucanase or avicelase, and Saha and Bothast (1996) reported $\beta$-glucosidase or cellobiase degrade the cellobiose to glucose.

The results of screening using the specific substrate indicated the yeast isolate have different activity for degradation of cellulosic substrate. Thus phenomenon indicated each isolate produce various cellulolytic enzymes. Prasertsan et al. (1992) reported 13 fungal showed FPase activity and only 8 isolates have CMCase activity.

The cellulase activity indicated the hallo around the colony with staining of Congo red. According to Johnson et al. (1986) and Onsori et al. (2005) (please confirm the year), the abilility of microorganism to degrade cellulose might detect by the clear zone (halo) around the colony after flooding with Congo red. Teather and Wood (1982) reported the congo red have the specific link with substrate polymer with $\beta$-(1,4)-glycosidic bound. According to Yuan et al. (2001), degradation of $\beta-1,4$ glycosidic bound caused the cellulose activity might caused the Congo red was unable to associated with polymer cellulose that caused production of clear zone on the medium.

Onsori et al. (2005) screened the genus Aspergillus based on the clear zone measurement. Kader and Omar (1998) described cellulolytic activity of 16 isolate fungus from Taman Sayap-Kinabalu, Sabah, Malaysia. The isolate with the highest index cellulose activity (CMCase) was S4121 among others isolate tested. Sudiana and Rahmansyah (2002) reported that 20 yeast isolate from soil from TNGH indicated the clear zone on assay CMCase activity using CMC as a substrate. Sudiana (2002) reported ability of 8 isolate bacteria from soil showed the CMCase indicate the clear zone around the bacterial colony on the medium $\mathrm{CMC}$ as a substrate. Murai et al. (1998) reported that CMCase as one of cellulase, break the $\beta-1,4$ glycosidic bound of the cellulose become shortchain cellooligosacaride. Congo red reacted with substrate CMC produce the link, where as the glucose or cellooligosacaride such as cellobiose do not the bound among them. Onsori et al. (2005) screened the 
Mal. J. Microbiol., Vol 7(4) 2011, 210-216

Table 2: Results of CMCase, avicelase, and cellobiase activity using specific substrate CMC, avicel, and cellobiose for 16 yeast isolate from TNGH

\begin{tabular}{|c|c|c|c|c|c|c|c|c|c|c|c|c|}
\hline \multirow[b]{2}{*}{ Isolate code } & \multicolumn{2}{|c|}{ Carboxymethyl cellulose } & \multirow{2}{*}{$\begin{array}{l}\text {-Medium } \\
\text { without } \\
\text { substrate }\end{array}$} & \multirow[b]{2}{*}{ ICA } & \multicolumn{2}{|l|}{ Avicel } & \multirow{2}{*}{$\begin{array}{l}\text {-Medium } \\
\text { without } \\
\text { substrate }\end{array}$} & \multirow{2}{*}{$e^{I C A}$} & \multicolumn{2}{|l|}{ Cellobiose } & \multirow{2}{*}{$\begin{array}{l}\text {-Medium } \\
\text { without } \\
\text { substrate }\end{array}$} & \multirow[b]{2}{*}{ ICA } \\
\hline & $\begin{array}{l}\text { Diameter } \\
\text { colony }(\mathrm{mm})\end{array}$ & $\begin{array}{l}\text { of Clear zone } \\
(\mathrm{mm})\end{array}$ & & & $\begin{array}{l}\text { Diameter of } \\
\text { colony }(\mathrm{mm})\end{array}$ & $\begin{array}{l}\text { Clear zone } \\
(\mathrm{mm})\end{array}$ & & & $\begin{array}{l}\text { Colony } \\
\text { diameter } \\
(\mathrm{mm})\end{array}$ & $\begin{array}{l}\text { Clear zone } \\
(\mathrm{mm})\end{array}$ & & \\
\hline S 4121 & 34.28 & 38.938 & 0 & 3.867 & 0 & 0 & 0 & 0 & 0 & 0 & 0 & 0 \\
\hline S 4132 & 24.346 & 27.869 & 0 & 2.484 & 0 & 0 & 0 & 0 & 0 & 0 & 0 & 0 \\
\hline S 4134 & 23.975 & 26.946 & 0 & 2.368 & 0 & 0 & 0 & 0 & 26.182 & 26.182 & 0 & 2.273 \\
\hline S 4215 & 0 & 0 & 0 & 0 & 0 & 0 & 0 & 0 & 15.8 & 15.8 & 0 & 0.975 \\
\hline S 42315 & 34.675 & 37.488 & 0 & 3.69 & 0 & 0 & 0 & 0 & 21.294 & 21.5 & 0 & 1.688 \\
\hline S 42318 & 0 & 0 & 0 & 0 & 0 & 0 & 0 & 0 & 10.696 & 10.696 & 0 & 0.337 \\
\hline S 4321 & 0 & 0 & 0 & 0 & 0 & 0 & 0 & 0 & 25.079 & 26.238 & 0 & 2.28 \\
\hline W 41210 & 0 & 0 & 0 & 0 & 0 & 0 & 0 & 0 & 11.267 & 12.708 & 0 & 0.589 \\
\hline W 41320 & 0 & 0 & 0 & 0 & 0 & 0 & 0 & 0 & 30.538 & 35.275 & 0 & 3.409 \\
\hline W 4233 & 12.992 & 13.513 & 0 & 0.689 & 12.963 & 12.963 & 0 & 0.620 & 16 & 16 & 0 & 1 \\
\hline W 4234 & 11.888 & 15.946 & 0 & 0.993 & 0 & 0 & 0 & 0 & 0 & 0 & 0 & 0 \\
\hline W 42317 & 25.096 & 28.8 & 0 & 2.6 & 0 & 0 & 0 & 0 & 22.657 & 26.957 & 0 & 2.37 \\
\hline SD 41124 & 0 & 0 & 0 & 0 & 0 & 0 & 0 & 0 & 13.65 & 13.65 & 0 & 0.706 \\
\hline SD 4124 & 0 & 0 & 0 & 0 & 0 & 0 & 0 & 0 & 16.063 & 16.063 & 0 & 1.008 \\
\hline SD 41219 & 0 & 0 & 0 & 0 & 0 & 0 & 0 & 0 & 12.354 & 13.684 & 0 & 0.711 \\
\hline SD 4223 & 0 & 0 & 0 & 0 & 0 & 0 & 0 & 0 & 14.946 & 15.459 & 0 & 0.932 \\
\hline $\begin{array}{l}\text { P } 2112 \\
\text { (positive control) } \\
\text { Y-17 }\end{array}$ & 11.688 & 21.488 & 0 & 1.69 & 0 & 0 & 0 & 0 & 12.583 & 0 & 0 & 0 \\
\hline $\begin{array}{l}\text { (negative } \\
\text { controle) }\end{array}$ & 10.006 & 0 & 0 & 0 & 0 & 0 & 0 & 0 & 0 & 0 & 0 & 0 \\
\hline $\begin{array}{l}\text { Medium } \\
\text { controle }\end{array}$ & 0 & 0 & 0 & 0 & 0 & 0 & 0 & 0 & 0 & 0 & 0 & 0 \\
\hline
\end{tabular}

Notes: ICA (Indexs Cellulase Activity) = 
CMCase of Aspergillus sp. stain with congo red to indicate the clear zone around the colony.

In this study, we investigated the yeast identity based on the sequence analysis of D1/D2 region of LSU rDNA. According to Kurtzman and Robnett (1998), yeast isolates were identified as the same species by the $99 \%$ similarity sequence of D1/D2 region of LSU rDNA. Our comparative analysis of the D1/D2 of LSU rDNA data of the strain UICC Y-286 (S4121) and other sequences D1/D2 of LSU rDNA available in the international DNA database Genbank (http://blast.ncbi.nlm.nih.gov) revealed that this strain was highly related to Trichosporon coprophilum Sugita, Takashima and Kikuchi, exhibiting sequence identity value $99 \%$ and related to Trichosporon sporotrichoides with value $98 \%$. Based on the species guideline of Kurtzman and Robnett (1998), this strain should be identified as Trichosporon coprophilum because it showed the higher sequence similarity value compare than to $T$. sporotrichoides. However since there is no valid description of species of $T$. coprophilum, this strain was identified as $T$. sporotrichoides (van Oorschot) van Oorschot and de Hoog which has been published in 1981 by van Oorschot and de Hoog.

\section{CONCLUSIONS}

Screening of 245 isolate yeast from TNGH using substrate cellulose-azure $0.2 \%$ were obtained sixteen isolate have positive of cellulase activity. The selected strain further screened using specific substrate (CMC, avicel, and cellobiose), out of seven isolate produced CMCase, six isolate produced cellobiase, two isolate produced CMCase and cellobiase, and one isolate produced CMCase, avicelase and cellobiase. Isolate S 4121 produced the highest CMCase $(3,867)$ was molecular identify as $T$. sporotrichoides.

\section{REFERENCES}

Altschul, S. F., Thomas, L. M., Schaffer, A. A., Zhang, J., Zhang, Z., Miller, W. and Lipman, D. J. (1997). Gapped BLAST and PSI-BLAST: A new generation of protein database search programs. Nucleic Acids Research 25, 3389-3402.

Coral, G., Arikan, B., Ünaldi, M. N. and Güvenmez, H. (2002). Some properties of crude carboxymethyl cellulose of Aspergillus niger Z10 wild-type strain. Turkey Journal of Biological 26, 209-213.

Fadel, M. (2000). Production physiology of cellulases and $\beta$-glucosidase enzymes of Aspergillus niger grown under solid state fermentation conditions. OnLine Journal of Biological Sciences 1(5), 401-411.

Gutell, R. R. and Fox, G. (1988). Compilation of large subunit RNA sequences presented in a structural format. Nucleic Acids Research 16(suppl.), r175r269.

Han, S. J., Yoo, Y. J. and Kang, H. S. (1995). Characterization of bifunctional cellulase and its structural gene. The Journal of Biological Chemistry 270(43), 26012-26019.
IImen, M., Saloheimo, A., Onnela, M. and Penttila, M. E. (1997). Regulation of cellulase gene expression in the filamentous fungus Trichoderma reesei. Applied and Environmental Microbiology 63(4), 1298-1306.

Johnson, J. A., Wong, W. K. R. and Beatty, J. T. (1986). Expression of cellulose gene in Rhodobacter capsulatus by use of plasmid expression vectors. Journal of Bacteriology 167(2), 604-610.

Kader, A. J. and Omar, O. (1998). Isolation of cellulolytic fungi from Sayap-Kinabalu Park, Sabah. ASEAN Review of Biodiversity and Environmental Conservation (ARBEC) 2, 1-6.

Kim, C. (1995). Characterization and substrate specificity of an endo- $\beta-1,4-D$-glucanase I (avicelase I) from an extracellular multienzyme complex of Bacillus circulans. Applied and Environmental Microbiology 61(3), 959-965.

Kubicek, C. P., Messner, R., Gruber, F., Mach, R. L. and Kubicek-Pranz, E. M. (1993). The Trichoderma cellulase regulatory puzzle: From the interior life of a secretory fungus. Enzyme and Microbial Technology $15,90-97$.

Kurtzman, C. P. and Robnett, C. J. (1998). Identification and phylogeny of ascomycetous yeasts from analysis of nuclear large subunit (26S) ribosomal DNA partial sequences. Antonie van Leeuwenhoek 73, 331-371.

Lim, G., Khew, E. and Yeoh, H. H. (1985). Extracellular enzyme of some black aspergilli in Singapore. MIRCEN Journal 1, 55-61.

Murai, T., Ueda, M., Kawaguchi, T., Arai, M. and Tanaka, A. (1998). Assimilation of cellooligosaccharides by a cell surface-engineered yeast expressing $\beta$-glucosidase and carboxymethylcellulase from Aspergillus aculeatus. Applied and Environmental Microbiology 64(12), 4857-4861.

Ojumu, T. V., Solomon, B. O., Betiku, E., Layokun, S. K. and Amigun, B. (2003). Cellulase production by Aspergillus flavus Linn isolate NSPR 101 fermented in sawdust, bagasse and corncob. African Journal of Biotechnology 2(6), 150-152.

Onsori, H., Zamani, M. R., Motallebi, M. and Zarghami, N. (2005). Identification of over producer strain of endo- $\beta-1,4$-glucanase in Aspergillus Species: Characterization of crude carboxymethyl cellulase. African Journal of Biotechnology 4(1), 26-30.

Prasertsan, P., H-kittikul, A. and Chitmanee, B. (1992). Isolation and selection of cellulolytic fungi from palm oil mill effluent. World Journal of Microbiology and Biotechnology 8, 614-617.

Raimbault, M. (1998). General and microbiological aspects of solid substrate fermentation. Electronic Journal of Biotechnology 1(3), 1-15.

Saha, B. C. and Bothast, R. J. (1996). Production, purification, and characterization of a highly glucosetolerant novel $\beta$-glucosidase from Candida peltata. Applied and Environmental Microbiology 62(9), 31653170. 
Sjamsuridzal, W. and Oetari, A. (2003). Rapid preparation of fungal and bacterial genomic DNA for PCR. Hayati 10, 122-124.

Skory, C. D. and Freer, S. N. (1995). Cloning and characterization of a gene encoding a cell-bound, extracellular $\beta$-glucosidase in the yeast Candida wickerhamii. Applied and Environmental Microbiology 61(2), 518-525.

Smith, R. E. (1977). Rapid tube test for detecting fungal cellulose production. Applied and Environmental Microbiology 33(4), 980-981.

Sudiana, I. M. (2002). Characteristic of CMCase of Bacillus sp isolated from soil of Gunung Halimun National Park (West Java, Indonesia). Berita Biologi (Indonesia) Edisi Khusus 6(1), 131-136.

Sudiana, I. M. and Rahmansyah, M. (2002). Species and functional diversity of soil microflora at Gunung Halimun National Park. BCP JICA.

Teather, R. M. and Wood, P. J. (1982). Use of congo red-polysaccharide interactions in enumeration and characterization of cellulolytic bacteria from the bovine rumen. Applied and Environmental Microbiology 43(4), 777-780.

Van Oorschot, C. A. N. and de Hoog, G. S. (1981). Dimorphic behaviour and taxonomy of Trichosporiella sporotrichoides. Antonie van Leeuwenhoek 47, 353366.

Van der Walt, J. P. and Yarrow, D. (1984). Methods for the isolation, maintenance, classification and identification of yeasts. In: The yeasts: A taxonomic study. Kreger-van Rij (ed.). $3^{\text {rd }}$ rev edn. Elsevier Science Publishers B.V., Amsterdam. pp. 45-105.

White, T. J., Bruns, T., Lee, S. and Taylor, J. (1990). Amplification and direct sequencing of fungal ribosomal RNA genes for phylogenetics. In: PCR Protocols: A Guide to Methods and Applications. Innis, M. A., Gelfand, D. H., Sninsky, J. J. and White, T. J. (eds.). Academic Press Incorporation, San Diego. pp. 315-322.

Yuan, S., Wu, Y. and Cosgrove, D. J. (2001). A fungal endoglucanase with plant cell extension activity. Plant Physiology 127, 324-333. 